\title{
The Growth Process of Informal Enterprises in Sub-Saharan Africa: A Case Study of a Metalworking Cluster in Nairobi
}

\author{
Tetsushi Sonobe \\ Foundation for Advanced Studies on International Development \\ and National Graduate Institute for Policy Studies, Tokyo \\ John Akoten \\ Institute of Policy Analysis and Research, Nairobi \\ Keijiro Otsuka \\ Foundation for Advanced Studies on International Development \\ and National Graduate Institute for Policy Studies, Tokyo
}

\begin{abstract}
Small and informal enterprises are preponderant in Africa's manufacturing sector. Their growth is negligibly low except when young and small, but little is known beyond this. This paper reports the results of our field study of a metalworking cluster in Nairobi. As competition was intensified by the entry of new enterprises, the education level of entrepreneurs became important in determining enterprise performance, which is reminiscent of East Asian experiences. Recently, some enterprises have left for formal industrial areas partly because their original sites have become too congested for them to grow and partly because being formal facilitates marketing and further growth.
\end{abstract}

Keywords Africa, Kenya, industrial development, informal sector, human capital JEL classification $\mathrm{O} 14 \cdot \mathrm{O} 33 \cdot \mathrm{O} 55$ 


\section{Introduction}

The manufacturing sector in Sub-Saharan Africa is dominated by very small and informal enterprises, and the majority of them grow only when they are young, as Collier and Gunning (1999), Tybout (2000), and Bigsten and Söderbom (2006) among others attest. Because of the lack of growth, their job creation falls far short of what they are expected to achieve. A number of possibly serious hindrances to enterprise growth have been enumerated in the literature. For example, Sleuwaegen and Goedhuys (2002) argue that small and informal enterprises are reluctant to become large because being large requires being formal and, thus, being subject to excessive regulations. Collier and Gunning (1999) among others call attention to market failures in insurance and credit markets, which would be especially serious for very small enterprises.

In their excellent review of this literature on enterprise growth in Sub-Saharan Africa, Bigsten and Söderbom (2006, p. 260) conclude, while arguing among other things that uncertainty is more detrimental to capital investment than credit constraints: "Improving our understanding of why these major results are observed seems an important area for future research." Another interesting finding is the positive association between enterprise growth and the general human capital or formal education of entrepreneurs, which is reported by McPherson (1996), Ramachandran and Shah (1999), Goedhuys and Sleuwaegen (2000), Mengistae (2006), and Akoten and Otsuka (2007). How can we reconcile the positive effect of human capital on enterprise growth with the general observation that industries stay at stationary points with enterprises growing only when they are young and very small? 
Industrial clusters in Nairobi can be divided into formal and informal clusters. Formal clusters include the Export Processing Zones (EPZ) and the Industrial Area. Informal clusters are ubiquitous in Nairobi and tend to be sector-specific. There are three garment clusters: Kariobangi, Gikomba, and Uhuru (Akoten and Otsuka, 2007). Combined, they have about 500 garment enterprises with the rest of the stalls (648) being used for other activities. The market for the Eastlands cluster (i.e., Gikomba and Uhuru) is domestic, mainly in Nairobi and distant towns. In terms of their average employment size, Uhuru has 3.9 workers, Kariobangi has 2.5 workers, and Gikomba has 3.5 workers (Akoten and Otsuka, 2007). There are two metalworking clusters: Kariobangi (our study site) and Kamukunji. The former is further away from Nairobi than the latter, which is located in the outskirts of Nairobi near the main bus terminus. Kamukunji has about 2000 enterprises which produce charcoal cooking stoves, buckets, pans, kitchen utensils, wheel-barrows, watering cans, and small tools. Kamukunji's products are less sophisticated and tend to be of lower quality than those of Kariobangi. These clusters also produce a limited number of spare parts such as silencers, auto upholstery, and rubber bushes. The market for these clusters is mainly individuals from Nairobi, especially owners of commercial vehicles.

Our study site is called Kariobangi Light Industries since the local government designated it to be an area for artisans in 1989. Its development dates from the early 1980s, when the workers of formal-sector factories lost jobs as a consequence of the implementation of the Structural Adjustment Program (SAP) and began to establish garages and workshops along the main road. They cleared the bushes to construct roads inside the area. The current population of enterprises is about 300 , and half of them are related to metalworking. They call themselves Jua Kali in Swahili, meaning informal- 
sector artisans. ${ }^{1}$ This cluster is informal and may be categorized as what Altenburg and Meyer-Stamer (1999) call a "survival cluster of micro and small-scale enterprises," which produce generally low-quality products and sell them primarily at domestic markets. While the networking of enterprises within the cluster in the form of the transaction of parts and production services plays an important role, as in other clusters in developing countries, global buyers play no role in transmitting best practices and upgrading designs, production layouts, and skills (e.g., Humphrey 2003; Humphrey and Schmitz 2001). Since the government does not provide any support to this cluster except for having provided space initially, bureaucratic corruption is limited to illegal levies on factory operation in return for exemption from formal tax payments (Mbaku 1996).

Our data set contains recall information on five years, 1998, 2000, 2002, 2005, and 2006, during which some enterprises attempted to improve their products. In the 1990s and early 2000s, enterprises in Kariobangi Light Industries produced low-quality products, and there were many enterprises producing almost the same products, because the production of such products was easy but profitable when the producers were few in number. As the entry of new enterprises continued, however, the profitability of producing such low-quality products declined. Instead, improvement in the quality of products, together with the introduction of new marketing channels suitable to the improved products, became profitable. Although this cluster seems to have improved enterprise performance by knowledge transmission or spillovers as argued in the literature on industrial clusters (e.g., Humphrey 2003, Humphrey and Schmitz 2001),

\footnotetext{
${ }^{1}$ The literal translation of Jua Kali is "hot sun," and this term refers to informal-sector artisans because they work outside under the hot sun. See King (1996) for detailed descriptions of the activities and history of the Jua Kali sector in Kenya.
} 
the performance among enterprises differs greatly. We hypothesize that entrepreneurs become increasingly motivated to make the innovations that increase profitability, and that the more highly educated entrepreneurs are more likely to succeed in achieving such improvements. ${ }^{2}$

We found that the effects of the education level of entrepreneurs on employment size and its growth became stronger in later years than in earlier years. These results are consistent with the results of the eight case studies conducted in East Asia by Sonobe and Otsuka (2006). ${ }^{3}$ An interesting feature of our data is the inclusion of seven enterprises that left Kariobangi for formal industrial areas. To our knowledge, no existing study has traced such leavers and has compared the behavior and performance before and after becoming formal. The leavers told us that they left Kariobangi because they needed more spacious sites, and that their relocation facilitated marketing greatly by improving the reputation of the enterprises.

The rest of the paper is organized as follows. After explaining our method of data collection, the next section describes what products and services the enterprises at the Kariobangi Light Industries produce. Section 3 compares the characteristics of the leavers and the remaining group. This section also advances our hypotheses concerning the changing roles of the entrepreneurs' human capital in determining their enterprise performances. Hypothesis testing is carried out through regression analyses in Section 4. Section 5 concludes the paper with the policy implications.

\footnotetext{
${ }^{2}$ Rocha (2004) points our that more research on the impact of entrepreneurship on cluster development is needed.

${ }^{3}$ There are several studies which compare the performance of formal and informal enterprises using cross-section data in sub-Saharan Africa. Goedhuys and Sleuwaegen (2000) find the positive effect of formal registration on the growth of firm size in Côte d'Ivoire, whereas McPherson and Liedholm (1996) demonstrate the positive effect of firm size on formal registration in Niger and Swaziland.
} 


\section{Data}

At Kariobangi Light Industries, no census of the enterprises has been carried out in the past. The Kariobangi Jua Kali Association, however, estimated the number of manufacturing enterprises to be around 150 as of $2006 .{ }^{4}$ We included hardware shops in the sample because the production of fabricated metal products and hardware trading can be done by these enterprises and because sheet bending and some other services can be done by both metal product enterprises and hardware shops. We also added to the sample the seven leavers, who are defined as enterprises that have relocated from Kariobangi Light Industries to the Baba Ndogo Industrial Area or the Mukuru Kwa Njenga Industrial Area by the time of our survey. The association identified nearly 150 enterprises as satisfying our specifications. In September 2006, we attempted a survey of all these enterprises, but were only able to meet 127 entrepreneurs as shown.

Enterprises engaged in fabrication of metal products, such as steel windows, steel furniture, and simple machines, account for nearly $40 \%$ of enterprises. More than half of this group produces non-mechanical items, such as window frames, grilles, and furniture. The rest of this group produces mechanical devices, such as scale balances and flour mills. The producers of these simple machines tend to contract out the production of parts to small foundries and lathe turners located nearby. Besides such subcontracting, these parts makers produce simple repair parts for vehicles as well. Also, the lathe turners repair balance scales and parts for cars and simple machines, and produce hinges, bolts, and nuts that are used by producers of steel gates and furniture. These foundries and lathe turners constitute the second group in Kariobangi, accounting

\footnotetext{
${ }^{4}$ Those enterprises on the other side of the main roads that surround the Kariobangi Light Industries are excluded from this number as well as our sample.
} 
for about $30 \%$ of enterprises. The third group is engaged in car repair and is called garages or garage mechanics. Garages here include panel beaters. Thus, the division of labor is practiced among machine producers, non-mechanical fabricators, garages, and parts suppliers. Almost all of them procure materials from hardware traders. Therefore, our study site is characterized by a cluster of metalwork enterprises.

According to the leaders of the association, the entry of new enterprises was active throughout the 1990s but has declined since the early 2000s despite the favorable macroeconomic condition in recent years. Such an evolution of the number of new entrants may be explained as follows. The metal products produced in Kariobangi are obviously copies of imported products. In the 1980s and 1990s, the demand for lowquality but cheap substitutes for expensive imports would have been high because such substitutes were in short supply. Noticing that the pioneers earned high profits, followers began producing copies of the original product. As the number of producers increased, parts suppliers and hardware shops emerged, and all of them have benefited from the development of the division of labor. The proliferation of the producers of the same products would, however, lower the product prices and hence the profitability. When we gave this account of the evolution of the number of new entrants and profitability to 51 entrepreneurs who attended a workshop, all of them agreed with us. According to Sonobe and Otsuka (2006), a similar development process was observed in industrial clusters in Japan, Taiwan, and China.

Another reason for the decreasing entry of new enterprises is the increasing congestion and worsening insecurity in Kariobangi. The congestion has been aggravated by the increased population of inhabitants in the area. While the area is designated as industrial, it now has many three- to five-story buildings that use only the 
ground floor for businesses and the upper stories as apartments. The residents of these apartments complain of the noises and smells coming from the workshops. The hostile attitudes of the new inhabitants and the inflow of refugees from the neighboring countries have resulted in insecurity problems, which have become so serious that the association has organized a vigilante group by mobilizing jobless young men recently.

Table 1 presents proportion of the entrepreneurs who have worked for the formal sector, such as Indian and other foreign ventures, before they started their own businesses in Kariobangi. It is shown that $62 \%$ of enterprises have worked in the formal sector. There are 28 entrepreneurs who have experienced being both Jua Kali and workers in the formal sector, and 15 who have neither type of work experience. Among the seven leavers, two were Jua Kali from the beginning of their careers, four were skilled workers or middle managers at formal-sector factories, and one was a civil engineer employed by the government.

Why did so many entrepreneurs come from the formal sector to Kariobangi to become Jua Kali? A push factor would be the implementation of the SAP and the subsequent contraction of the formal manufacturing sector. Pull factors would be the initially high demand for cheap substitutes for imported products, which very small workshops could easily produce with inexpensive equipment while enjoying the benefits arising from the agglomeration. Fafchamps and Söderbom (2006) develop a model in which increases in employment size make it more difficult to monitor workers and necessitate offering higher wages to workers in order to discourage shirking. According to their estimates, the wage rate increases with the expansion of employment size more steeply in Sub-Saharan Africa than in Morocco. Jua Kali clusters like Kariobangi Light Industries would provide the skilled workers and middle managers of 
large formal-sector factories with lucrative outside opportunities and hence contribute to wage increases in the formal sector. ${ }^{5}$ The high wages would, in turn, weaken the competitiveness of the large factories and lead to further downsizing.

Table 1 also compares the leavers and the remaining group with respect to the enterprise size, which is measured by the number of workers. We found it much more difficult to obtain reliable data on other measures of enterprise size, such as value added and sales revenues, which seems to be a common problem in enterprise surveys in SubSaharan Africa in view of the fact that many studies of enterprise growth in the region focus on employment. Leavers employed 25.1 workers on average in 2006, whereas the remaining enterprises in Kariobangi employed only 5.1 workers on average. None of the parts suppliers left Kariobangi for formal industrial areas by 2006. Probably, parts suppliers have less incentive to leave because their major customers are in Kariobangi. ${ }^{6}$ The garage that entered the formal sector employed as many as 30 workers, whereas the garages that remain informal had only 4.3 workers on average. If all the activities are combined, the mean employment size of the leavers is four times as large as that of the remaining group, which is consistent with the finding of Goedhuys and Sleuwaegen (2000).

The leavers gave us three reasons for their relocation during our interviews with them. Firstly, the insecurity or the fear of being mugged in Kariobangi repelled prospective customers. Secondly, for prospective customers, Kariobangi and the term Jua Kali are synonymous with poor-quality products. Thirdly, unlike the formal industrial areas, Kariobangi has very poor infrastructure and little space for the

\footnotetext{
${ }^{5}$ In Nairobi, there are other Jua Kali clusters including the Kamukunji metalwork cluster, whose activities and history are described by Kinyanjui (2007).

${ }^{6}$ There are transactions between parts suppliers in Kariobangi and at least one of the leavers, however.
} 
expansion of operation. The first two reasons concern the difficulty in marketing in Kariobangi. The unreliable supply of electricity, which is included in the third reason, would discourage mechanization. Bumpy and muddy roads would make it difficult to ship high precision products. The limited space would directly constrain enterprise growth. Relocation to a formal industrial area would sweep away these problems, even though it is costly because of moving costs and regulations, including income tax payment.

\section{Human capital of entrepreneurs and enterprise performance}

Table 1 presents the data on the characteristics of entrepreneurs. The leavers are a little older (i.e., 45.6 years old in 2006) than the others, and they were 43.6 years old on average when their enterprises were relocated to formal industrial areas. The leavers have longer years of formal schooling and formal vocational training, longer work experience prior to starting their own businesses, and longer experience of management thereafter. To sum up, they are likely to have both more abundant general and specific human capital than the remaining group. In addition, four of the seven leavers have partners, who had similar backgrounds and would have been able to help the entrepreneurs. Four entrepreneurs inherited businesses from their parents, but the vast majority of the sample entrepreneurs started their own businesses.

In our definition, formal vocational training includes technical training in mechanical engineering at a polytechnic, but it does not include the study of mechanical engineering at a university. Instead, the latter is included in formal schooling. We include any training, whether provided at polytechnics or other institutions, in vocational training as opposed to schooling if it emphasizes practical aspects and 
attaches little importance to theoretical aspects. University education attaches importance to theories even in specialized courses such as mechanical engineering.

In our sample, more than 80 percent of the entrepreneurs received technical training or education either at vocational schools, colleges, or universities. The majority used to work at formal-sector factories. Judging from the educational and occupational backgrounds of the entrepreneurs, therefore, the cluster is considered to be fairly abundant in human capital specific to engineering areas.

Only one-third of the entrepreneurs knew what jigs and fixtures were, when they started their businesses (Sonobe et al. 2009b). Jigs and fixtures are small devices that lathe turners make to increase the precision and efficiency of their work. They are indispensable for the mass processing of high-precision parts. Fabricators may not use jigs or fixtures themselves but they should be interested to know whether the lathe turners processing parts for them use them. The low percentage of entrepreneurs with knowledge regarding jigs and fixtures indicates that the engineering knowledge held by the entrepreneurs when they started their businesses was limited. However as of 2006, the majority of the entrepreneurs of all types and more than 70 percent of the leavers and those with experience in the formal sector knew what jigs and fixtures were, even though only a few of them actually use them. This increase in knowledge suggests that the entrepreneurs are increasingly interested in the mass production of high-quality parts and products processed with lathes.

Despite this general improvement of production knowledge, some entrepreneurs continued to produce low quality products. Our discussion with the entrepreneurs reveals four reasons. First, because of stiff competition, some incapable entrepreneurs decided to target the low-end customers who do not mind about low quality. Second, 
most entrepreneurs who produce low quality products have low levels of education. This limits their capacity to learn and be innovative. Third, according to the local authority statutory requirement, all firms are supposed to pay for the Single Business Permit in order to operate. Since the production of higher-quality products requires a greater number of machines and tools, larger space is needed. This space cost increases the cost of producing high-quality products thereby hindering less capable entrepreneurs from upgrading their products. Fourth, because they use low quality materials, the products they produce are also of low quality.

On the other hand, some entrepreneurs are striving to upgrade their products. In our observation, the entrepreneurs become increasingly motivated to improve their product quality as the proliferation of producers intensifies competition and lowers the profitability of producing low-quality and standard products. However, the improvement of products itself will not increase profits unless buyers recognize the improved quality and appreciate it, as is attested by the case study of an electric appliance cluster in China conducted by Sonobe et al. (2004). Thus, differentiating an enterprise's own improved products clearly from inferior products produced by other enterprises through branding and establishing new own marketing channels becomes critically important. The improvement of product quality may be easy for the entrepreneurs in the Jua Kali cluster who are experienced engineers, but it would be difficult for those who did not understand the concept of precision. Upgrading marketing methods and finding new marketing channels would be more difficult still for almost all the entrepreneurs there. According to our respondents, information on better production techniques and marketing tend to be scarce because of friction in information flow within the cluster. Most entrepreneurs operate on a closed-door policy, 
thereby restricting competitors from visiting their workshops to obtain important information. Second, even when information is acquired, lack of credit prevents most entrepreneurs from importing better machines that they have learned of. Nonetheless, if they succeed in accomplishing these improvements, then their marginal revenue curve will shift upward and they will employ a greater number of workers than before. However, the expansion will make labor management more difficult than before. Thus, quality improvement will require improved labor management as well.

We call these improvements "multifaceted innovations," even though they do not refer to truly new applications of scientific discoveries or engineering inventions. Formal schooling would assume importance when new decisions are made in a dynamic context. Thus, we contend that those entrepreneurs with higher formal education are more likely to succeed in multifaceted innovations in product quality, marketing, and management. In view of the increasing importance of such innovations, a testable hypothesis may be postulated as follows:

Hypothesis 1: The effects of the formal education of the entrepreneurs on enterprise size and enterprise growth are positive and have increased over time in the Jua Kali cluster.

In our view, the recent relocation of the six leavers from the cluster to formal industrial areas is a result of the increased effects of schooling. Hypothesis 1 asserts that the education effects increased even among the remaining enterprises. Because innovations must be multifaceted, specialized vocational training without much emphasis on theoretical thinking will not be as useful as formal schooling for enterprise growth. Thus, we conjecture that the effects of vocational training on size and growth will become weaker relative to the effects of formal schooling. 
Turning to marketing, our hypothesis is that entrepreneurs become more motivated to market their products to the buyers who appreciate high quality, and that more educated entrepreneurs are more likely to succeed in such marketing. We may refer to the buyers who appreciate high quality as quality-conscious customers for convenience. According to Fafchamps (2004), nearly 80 percent of enterprises in nine countries in Sub-Saharan Africa sell the whole or part of their output to the end-users of their products such as manufacturers and consumers and the rest is sold to merchants. Exports account for only eight percent of their output. Similarly, at Kariobangi Light Industries, the most primitive but still the most common way of marketing among informal artisans and craftsmen is to wait for individuals to come to the workshops in the cluster to buy items for their own use. This marketing method accounts for 40 to 50 percent of their sales revenues. ${ }^{7}$

Marketing to merchants, i.e., wholesalers and retailers, requires that products of relatively uniform quality be produced in large quantities. In the garment industry in Nairobi, Akoten and Otsuka (2007) find that marketing to merchants is more profitable than selling to individual customers, and that more educated producers tend to have a higher propensity to sell to merchants. In Kariobangi, however, there seems to be no consensus of opinion regarding which marketing channel is more lucrative or which requires higher-quality products. Instead, the sample entrepreneurs would agree that it is challenging and hence profitable to sell products to foreign or international companies, government and non-government organizations in Kenya, or abroad. These customers are much more conscious about the quality of products than any other types of

\footnotetext{
${ }^{7}$ For the parts suppliers, the most important type of customers is metal product fabricators in the cluster, but sales to individuals account for a quarter of their revenues, because they accept repair work orders from individuals and sell simple car repair parts to individuals.
} 
customers that the enterprises in Kariobangi cater to. Thus, it seems reasonable to count them as quality-conscious customers.

The last part of Table 1 shows the trends in marketing to quality-conscious customers, as well as direct procurement of materials. ${ }^{8}$ Because a big order from a quality buyer may come suddenly toward the end of a year, the percentage of marketing to quality-conscious customers for the whole year can be ascertained only after the year has ended. Because we conducted the enterprise survey in September 2006, we could not obtain this percentage for 2006. This is why this table compares $1998 / 2000$ and 2005 instead of 2006. By 1998/2000, we mean the pooled data on the two years in 1998 and 2000. Although we obtained recall data on employment in 1998, 2000, 2002, 2005, and 2006, about 40 percent of the sample enterprises started business after 2000. To increase the number of observations up to the level comparable with the later period, we took the average of the first two years in the sample. The percentage of sales revenues from marketing to quality-conscious customers declined for the remaining enterprises, whereas it increased for the leavers. Based on our hypothesis that the major determinant of multifaceted innovations is formal schooling, we advance the following hypothesis:

Hypothesis 2: The effects of the formal education of the entrepreneurs on marketing to quality-conscious customers are positive and have increased over time in the Jua Kali cluster.

To test this hypothesis, we will examine the effect of education on the percentage of sales revenues from marketing to quality buyers. Table 1 also shows the percentage of the cost of material purchased directly from factories or trading houses as opposed to

\footnotetext{
${ }^{8}$ The data shown in Table 1 exclude the hardware shops and miscellaneous service providers since they have low percentages of marketing to quality-conscious customers due to the nature of their lines of trade.
} 
that purchased from hardware shops in the cluster or other merchants in Nairobi. ${ }^{9}$ Such direct procurement was an important aspect of the multifaceted innovations in the footwear industry in Ethiopia, according to Sonobe et al. (2009a). Like marketing to quality-conscious customers, the share of direct procurement decreased for each type of the remaining enterprises, but it increased for the leavers. These observations suggest that it is difficult to accomplish the multifaceted innovations in the Jua Kali cluster.

According to our discussions with the entrepreneurs, there are at least several reasons why most entrepreneurs do not market to higher-end firms. First, the statutory requirement that products to be sold to higher-end firms should bear the Kenya Bureau of Standards (KEBS) mark of quality is often prohibitively costly. Second, to produce high quality products for higher-end firms, better machines are required. However, virtually all entrepreneurs use second hand machines and this has hindered their capacity to produce high quality products. Third, their low level of education reduces the capacity of most entrepreneurs to produce better quality products by mimicking successful entrepreneurs or engaging in innovative activities. Fourth, poor accessibility to credit makes it challenging for entrepreneurs to sell to higher-end customers who prefer paying suppliers a month later after receiving a steady flow of supplies on credit for up to two months and selling them. These entrepreneurs cannot borrow from financial institutions because they lack appropriate collateral.

Such growth constraints are increasingly binding as the entrepreneurs are motivated to achieve quality improvement under the increasingly strong competitive pressure. Moreover, the worsening insecurity problem and the increasing congestion

\footnotetext{
${ }^{9}$ The lower portion of Table 1 also excludes the hardware shops and miscellaneous service providers. The hardware shops procure steel materials from Mombasa. Hence their percentages of direct procurement are much higher than other types of businesses. Some of the miscellaneous service providers are recycle businesses, whose direct purchase is difficult to define.
} 
are highly likely to tighten the constraint on enterprise growth. The growth constraint may reveal itself in the growth regression as the negative effect of the current enterprise size on the subsequent growth. Since the constraint is expected to be increasingly binding, we hypothesize as follows:

Hypothesis 3: The negative effect of the current enterprise size on its subsequent growth has become stronger over time in the Jua Kali cluster.

\section{Regression analyses}

\subsection{Specification}

In order to test Hypotheses 1 and 3, we estimate the functions that explain the number of workers and its growth rate in the sample that excludes the leavers. Because we are interested in the changes in the strength of the effect of schooling, we estimate these functions in each year or period separately to examine whether the coefficients change over time. We exclude the leavers in order to show that the importance of schooling for good enterprise performance has increased even among the remaining enterprises. The two functions to be estimated include such explanatory variables as the entrepreneur's years of schooling and some other characteristics shown in Table 1, as explanatory variables. The functions do not include all the variables, however, in order to avoid the problems of multicollinearity and endogeneity. Actually we exclude age from the regression. The dummy variable indicating whether the entrepreneur has work experience in the formal sector turned out to be positively and closely correlated with the years of schooling and the years of vocational training. These variables are excluded from the regression. The correlation coefficients among major dependent and independent variables are shown in Table 2. 
The function that explains enterprise growth includes the same set of explanatory variables representing the characteristics of the entrepreneur. It also includes the logarithm of the number of workers in the initial year of the period. This is a conventional specification of the growth regression used in the literature of enterprise growth as well as of cross-country growth comparison. The OLS estimation of this regression equation, however, is subject to the endogeneity bias arising from the correlation between the initial size and the error term (e.g. Caselli et al. 1996). A sophisticated approach to this problem may be to employ GMM estimators such as the Arellano and Bond (1991) estimator, which uses the lagged variables as instruments for the first difference equation. Bigsten and Gebreeyesus (2007) apply this approach to the panel data on the manufacturing enterprises in Addis Ababa. This approach, however, cannot be applied to our data because the data do not have enough length in the timeseries dimension.

Instead, we instrumented the initial enterprise size with some of the variables representing the characteristics of the entrepreneur. In other words, we use the estimation of the function that explains the enterprise size as the first stage of the twostage least square (2SLS) regression. According to Hypothesis 1, formal education has positive impacts on both the size and growth of an enterprise, and by contrast, vocational training, prior work experience, and management experience will have significant impacts only on enterprise size. Thus, we attempt 2SLS regressions based on the assumption that the years of vocational training, the years of prior work experience, and the years of management of the current business serve as instruments. 
The validity of this assumption is checked by conducting the first-stage $F$ test and the over-identification test. ${ }^{10}$

To test Hypothesis 2, we regress the fraction of the sales revenues from qualityconscious customers and the proportion of the direct procurement of materials on the same set of explanatory variables as the enterprise size and growth regressions, using the sample that excludes the leavers. Since the fraction is censored from below at 0 , we use the Tobit model specification. ${ }^{11}$

\subsection{Estimation Results}

Table 3 presents the results of the growth regressions. Six dummy variables indicating activity types are also used to control for the effects common to the enterprises of the same activity type. The default for these activity-type dummies is the metal product fabrication other than the production of scale balances, such as the fabrication of steel windows, steel furniture, and flour mills. The first two columns cover the two periods from 1998 to 2000 and from 2000 to 2002 . The data on the two periods are pooled, and the unobserved fixed effects, if any, are not treated as in the panel fixed-effect model. Column (1) shows the OLS estimates and column (2) shows the 2SLS estimates. Likewise, columns (3) and (4) show the OLS and 2SLS estimates, respectively, based on the pooled data of the two periods, 2002-2005 and 2005-2006. The dependent variable is the annual growth rate of the number of workers during each period. In the 2SLS regressions, the initial employment size is instrumented with the years of

\footnotetext{
${ }^{10}$ In order to save space, we do not report the results of the first-stage regression of the enterprise size. See Sonobe et al. (2009b) for the estimation results.

${ }^{11}$ We also run panel fixed-effects regressions to examine the effect of the relocation from the cluster to a formal industrial area. The dependent variable is the number of workers, and the main explanatory variable is the dummy variable that indicates whether the enterprise remains in the Kariobangi Light Industry or in a formal industrial area in the year. The result shows that the relocation is significantly associated with an increase in the number of workers (Sonobe et al. 2009b).
} 
vocational training, prior work experience, and management, as mentioned earlier. These variables have jointly significant effects in the first-stage regression in both the early two periods and the latter two periods, as shown toward the bottom of Table 3, even though only the years of management had a significant effect in 2002 and 2005. The results of the over-identification test $a$ la Davidson and MacKinnon (1993) indicate that these instrumental variables do not have any direct effect on enterprise growth.

In the early two periods, the OLS and 2SLS estimates of the growth equation are similar, and both indicate that the years of schooling had no significant effect on enterprise growth. In the later two periods, however, the 2SLS estimate of the effect of the initial employment size is much larger in absolute terms than the OLS estimate, and the effect of the years of schooling is positive and highly significant in both specifications. The result that the effect of schooling was strengthened in the later periods supports Hypothesis 1. To the extent that the initial employment size is endogenous, the OLS estimates are inconsistent. That the consistent 2SLS estimate of the effect of the initial size became greater in absolute terms lends strong support to Hypothesis 3.

Although not reported in the table, here too, the effects of the explanatory variables on growth remain qualitatively unchanged if the leavers are included in the sample. The magnitudes of the effects are changed as follows. Firstly, the inclusion of the leavers weakens the negative effect of the initial employment size compared with the result in column (4). Put differently, the growth constraint is estimated to be less severe if the leavers are included in the sample, suggesting that the relocation from Kariobangi to the formal industrial area relaxes the growth constraint. Secondly, the inclusion of the leavers strengthens the growth effect of schooling, especially in the later 
periods. This is probably because the leavers tend to have high education, and their growth rates were much higher than the average, especially after their relocation.

Table 4 shows the estimates of the functions explaining marketing to qualityconscious customers and the direct procurement of materials. The first two columns indicate clearly that the positive effect of schooling became stronger and that of vocational training became weaker in 2005 than in 1998/2000. Although not shown in the table, the estimates of these effects for 2002 are in-between those for 1998/2000 and 2005. These results support Hypothesis 2. If the leavers are included in the sample, the effect of schooling becomes stronger in each year and even stronger in 2005. It is difficult to explain why the effect of the years of management was negative and significant in 1998/2000 and insignificant in 2005 and why that of the years of prior experience was negative and significant in 2005 and insignificant in 1998/200. However, these results suggest that experience as a worker or an entrepreneur is not very helpful in increasing the sale to quality-conscious customers. According to

columns (3) and (4), formal schooling became more important in 2005 than in $1998 / 2000$ for entrepreneurs to increase the direct procurement of materials as well. Vocational training, prior experience, and management experience did not have any significant effects on direct procurement in either year.

\section{Conclusions}

This paper has investigated the changing determinants of the size and growth of informal enterprises in Sub-Saharan Africa, taking a Jua Kali metalworking cluster in Nairobi as an example. Based on the experience of East Asia described by Sonobe and Otsuka (2006), we hypothesized that entrepreneurs become increasingly motivated to 
make the multifaceted innovations that increase profitability, and that the more highly educated entrepreneurs are more likely to succeed in achieving such improvements. We also hypothesized that the multifaceted innovations (and the resulting growth in enterprise size) are difficult to achieve as long as the enterprises remain in the informal cluster. The testable implications derived from these basic hypotheses are strongly supported by the descriptive data.

The results of the regression analyses more clearly indicate that while the relative advantage of improving product quality is increasing in the Jua Kali cluster, it is difficult to find customers who appreciate the high quality of products and to find space to expand operations. Such growth constraints faced by the enterprises remaining in the cluster are becoming more severe. The question may arise as to why they hesitate to move to formal industrial areas, where they can further the multifaceted innovations and expand operations. For them to become formal, they need to be able to generate high profits that exceed the moving cost and other fixed costs associated with the relocation and transformation from an informal to formal enterprise. These costs include the cost of product certification by the Kenya Bureau of Standards, the cost of renting a large workshop, and the cost of meeting other statutory requirements. In addition to such costs, uncertainty seems to make them hesitant. To sum up, while the majority of enterprises in Sub-Saharan Africa do not grow partly because of the growth constraints of congested clusters and partly because of the lack of entrepreneurial ability of managers, some enterprises managed by educated owners grow successfully by taking the risk of introducing new management strategies including relocation.

Such ability and uncertainty are the functions of knowledge, however. If the entrepreneur is more knowledgeable, he is more likely to generate high profits by 
achieving the multifaceted innovations successfully, and his assessment of profitability will be more accurate. According to our interviews with a large number of enterprise managers, formal education as well as work experience in the formal sector is the key to learning improved production methods and upgrading product quality, which, in turn, makes it possible to sell final products to higher-end users. To be truly successful, an entrepreneur must convey quality information to users properly. Tacit, non-codifiable, and valuable know-how in metal work and specifically developed marketing channels based on trust with end-users are unlikely to be imitated easily by competing firms in the cluster.

It is critically important for policymakers in Sub-Saharan Africa to recognize that informal clusters may be able to encourage and support firm growth and eventual formalization, even without the assistance from formal clusters and global value chains. Such development has widely occurred in East Asia (Sonobe and Otsuka 2006). To support the growth of informal clusters further and their job creation in Sub-Saharan Africa, it is highly desirable for the government, foreign aid agencies, and NGOs to assist the remaining entrepreneurs in following suit. An effective strategy for this purpose is to provide entrepreneurs with training programs that teach them how to achieve the multifaceted innovations in products, marketing, and management simultaneously. ${ }^{12}$

\footnotetext{
${ }^{12}$ In collaboration with the World Bank, such a training program was offered in Kariobangi in April 2008. It is too early to judge, however, how effective such a program will be.
} 


\section{Acknowledgements}

This paper has benefited from the helpful comments and suggestions of an anonymous referee of this journal. Many thanks are also due to Paul Kandasamy for helping us editing the paper. Also financial support of the Global Center of Excellence project funded by the Ministry of Education and Science of the Japanese government is gratefully acknowledged.

\section{References}

Akoten, J.E. \& Otsuka, K. (2007). From tailors to mini-manufacturers: The role of traders in the transformation of garment enterprises in Nairobi. Journal of African Economies 16(4), 564-595.

Altenburg, T. \& Meyer-Stamer, J. (1999). How to promote clusters: Policy experience from Latin America. World Development 27 (9), 1693-1713.

Arellano M. \& Bond S. (1991). Some tests of specification for panel data: Monte Carlo evidence and an application to employment equations. Review of Economic Studies 58(2), 277-297.

Bigsten, A. \& Gebreeyesus M. (2007). The small, the young, and the productive:

Determinants of manufacturing firm growth in Ethiopia. Economic Development and Cultural Change 55(4), 813-840.

Bigsten, A. \& Söderbom, M. (2006). What have we learned from a decade of manufacturing enterprise surveys in Africa? World Bank Research Observer 21(2), 241-265. 
Caselli, F., Esquivel, G. \& Lefort, F. (1996). Reopening the Convergence Debate: A New Look at Cross-Country Growth Empirics. Journal of Economic Growth, 1(3), 363-390.

Collier P. \& Gunning J. W. (1999). Explaining African economic performance. Journal of Economic Literature, 37(1), 64-111.

Davidson, R. \& MacKinnon, J.G. (1993). Estimation and inference in econometrics. (Oxford: Oxford University Press).

Fafchamps, M. (2004). Market institutions in sub-Saharan Africa: Theory and evidence. (Cambridge, MA: The MIT Press).

Fafchamps, M. \& Söderbom, M. (2006). Wages and labor management in African manufacturing. Journal of Human Resources, 41(2), 346-379.

Goedhuys, M. \& Sleuwaegen, L. (2000). Entrepreneurship and growth of entrepreneurial firms in Côte d'Ivoire. Journal of Development Studies, 36(3), $122-145$.

Humphrey, J. (2003). Opportunities for SMEs in developing countries to upgrade in a global economy. SEED Working Paper No. 43, International Labor Organiation.

Humphrey, J. \& Schmitz, H. (2001). Governance in global value chains. IDS Bulletin 32.3, Institute of Development Studies.

King, K. (1996). Jua Kali Kenya: Change \& Development in an Informal Economy 1970/95. (London: James Currey; Nairobi: East African Education Publisher; and Athens: Ohio University Press).

Kinyanjui, N. (2007). The Kamukunji metalwork cluster in Kenya. (In D. Z. Zeng (Ed.), Knowledge, technology, and cluster-based growth in Africa, WBI Development Studies, Washington, DC: The World Bank). 
Mbaku, J. M. (1996). Bureaucratic corruption in Africa: The futility of cleanups. Cato Journal 16 (1), 99-118.

McPherson, M. (1996). Growth of micro and small enterprises in southern Africa. Journal of Development Economics, 48 (2), 253-277.

McPherson, M. A. \& Liedholm, C. (1996). Determinants of small and micro enterprise registration: Results from surveys in Niger and Swaziland. World Development, 24(3), 481-487.

Mengistae, T. (2006). Competition and entrepreneurs' human capital in small business longetivity and growth. Journal of Development Studies, 42 (5), 812-836.

Ramachandran, V. \& Shah, M. K. (1999). Minority entrepreneurs and firm performance in Sub-Saharan Africa. Journal of Development Studies, 36 (2), 71-87.

Rocha, H. O. (2004). Entrepreneurship and development: the role of clusters. Small Business Economics 23 (5), 363-400.

Sleuwaegen, L. \& Goedhuys, M. (2002). Growth of firms in developing countries: Evidence from Côte d'Ivoire. Journal of Development Economics, 68 (1), 117135.

Sonobe, T., Akoten J.E. \& Otsuka, K. (2009a). An exploration into the successful development of the leather-shoe industry in Ethiopia. Review of Development Economics, forthcoming.

Sonobe, T., Akoten J.E. \& Otsuka, K. (2009b). The growth process of informal enterprises in a metalworking cluster in Nairobi. FASID Discussion Paper

Sonobe, T., Hu, D. \& Otsuka, K. (2004). From inferior to superior products: An inquiry into the Wenzhou model of industrial development in China. Journal of Comparative Economics, 32 (3), 542-563. 
Sonobe, T. \& Otsuka, K. (2006). Cluster-based industrial development: An East Asian model. (Basingstoke: Palgrave Macmillan).

Tybout J. R. (2000). Manufacturing firms in developing countries: how well do they do, and why? Journal of Economic Literature, 38(1), 11-44.

Zeng, D. Z. (Ed.) (2007). Knowledge, technology, and cluster-based growth in Africa. (WBI Development Studies, Washington, DC: The World Bank). 
Table 1 Average characteristics of managers of sample enterprises, and their size and marketing channels

\begin{tabular}{|c|c|c|c|}
\hline & Total & Leavers & Remaining group \\
\hline Sample size & 127 & 7 & 120 \\
\hline Experience in formal sector (\%) & 62 & 71 & 62 \\
\hline Age in 2006 & 40.0 & 45.6 & 39.7 \\
\hline Years of schooloing & 11.0 & 13.0 & 10.9 \\
\hline Years of vocational training & 1.0 & 2.6 & 0.9 \\
\hline $\begin{array}{c}\text { Years of prior experience in } \\
\text { similar businesses }\end{array}$ & 4.2 & 8.7 & 3.9 \\
\hline Years of management experience & 7.6 & 9.3 & 7.5 \\
\hline Employment size in 2006 & 6.2 & 25.1 & 5.1 \\
\hline in $1998 / 2000$ & 4.5 & 17.0 & 4.0 \\
\hline \multicolumn{4}{|l|}{$\begin{array}{l}\text { Marketing to quality-conscious } \\
\text { customers ( } \% \text { of revenue) }\end{array}$} \\
\hline in 2005 & 12.4 & 55.0 & 6.2 \\
\hline in $1998 / 2000$ & 9.6 & 51.0 & 9.2 \\
\hline \multicolumn{4}{|l|}{$\begin{array}{c}\text { Direct procurement ( } \% \text { of } \\
\text { material cost) }\end{array}$} \\
\hline in 2005 & 27.1 & 50.7 & 28.8 \\
\hline in $1998 / 2000$ & 28.9 & 31.0 & 25.4 \\
\hline
\end{tabular}


Table 2 Correlation matrix among major dependent and independent variables

\begin{tabular}{|l|c|c|c|c|c|c|c|}
\hline & L & GL & $\begin{array}{c}\text { Market- } \\
\text { ing }\end{array}$ & $\begin{array}{c}\text { School- } \\
\text { ing }\end{array}$ & VOC & EXP & $\begin{array}{c}\text { MGT- } \\
\text { EXP }\end{array}$ \\
\hline Employment size (L) & 1.00 & & & & & & \\
\hline Growth rate of L & .22 & 1.00 & & & & & \\
\hline $\begin{array}{l}\text { Marketing to quality- } \\
\text { conscious customers }\end{array}$ & .34 & .05 & 1.00 & & & & \\
\hline $\begin{array}{l}\text { Schooling years of } \\
\text { managers }\end{array}$ & .36 & .07 & .25 & 1.00 & & & \\
\hline $\begin{array}{l}\text { Years of vocational } \\
\text { training (VOC) }\end{array}$ & .15 & -.03 & .19 & .20 & 1.00 & & \\
\hline $\begin{array}{l}\text { Years of prior } \\
\text { experience (EXP) }\end{array}$ & .27 & -.12 & .07 & .17 & .11 & 1.00 & \\
\hline $\begin{array}{l}\text { Years of management } \\
\text { experience (MGT-EXP) }\end{array}$ & .31 & -.17 & .02 & -.00 & .15 & .08 & 1.00 \\
\hline
\end{tabular}


Table 3 OLS and 2SLS regression estimates of the effect of entrepreneurs' human capital on employment growth in the sample excluding the leavers ${ }^{\text {a }}$

\begin{tabular}{|c|c|c|c|c|}
\hline & \multicolumn{2}{|c|}{$\underline{1998-2000 \text { and } 2000-2002}$} & \multicolumn{2}{|c|}{$2002-2005$ and $2005-2006$} \\
\hline & OLS & 2SLS & OLS & 2SLS \\
\hline & $(1)$ & & & (4) \\
\hline Lagged log of employment $^{b}$ & $\begin{array}{c}-0.073 * * * \\
(-2.81)\end{array}$ & $\begin{array}{c}-0.083 * * \\
(-2.40)\end{array}$ & $\begin{array}{c}-0.064 * \\
(-1.66)\end{array}$ & $\begin{array}{c}-0.299 * * \\
(-2.53)\end{array}$ \\
\hline Years of schooling & $\begin{array}{c}0.008 \\
(1.20)\end{array}$ & $\begin{array}{l}0.008 \\
(1.19)\end{array}$ & $\begin{array}{c}0.030 * * * \\
(2.64)\end{array}$ & $\begin{array}{c}0.050 * * * \\
(3.30)\end{array}$ \\
\hline Years of vocational training & $\begin{array}{l}0.004 \\
(0.40)\end{array}$ & & $\begin{array}{l}-0.001 \\
(-0.05)\end{array}$ & \\
\hline Years of prior experience & $\begin{array}{l}-0.006 \\
(-1.02)\end{array}$ & & $\begin{array}{l}0.004 \\
(0.69)\end{array}$ & \\
\hline Years of management & $\begin{array}{l}0.001 \\
(0.35)\end{array}$ & & $\begin{array}{c}-0.014 * * \\
(-2.51)\end{array}$ & \\
\hline Soap making dummy & $\begin{array}{c}0.264 * * * \\
(2.66)\end{array}$ & $\begin{array}{c}0.272 * * * \\
(4.21)\end{array}$ & $\begin{array}{l}-0.247 \\
(-1.64)\end{array}$ & $\begin{array}{l}-0.120 \\
(-0.50)\end{array}$ \\
\hline Car repair dummy & $\begin{array}{l}-0.023 \\
(-0.41)\end{array}$ & $\begin{array}{l}-0.002 \\
(-0.05)\end{array}$ & $\begin{array}{l}-0.095 \\
(-1.04)\end{array}$ & $\begin{array}{l}-0.043 \\
(-0.44)\end{array}$ \\
\hline Parts dummy & $\begin{array}{l}-0.060 \\
(-1.29)\end{array}$ & $\begin{array}{l}-0.043 \\
(-0.89)\end{array}$ & $\begin{array}{l}-0.041 \\
(-0.62)\end{array}$ & $\begin{array}{l}-0.053 \\
(-0.67)\end{array}$ \\
\hline Balance dummy & $\begin{array}{l}-0.090 \\
(-1.36)\end{array}$ & $\begin{array}{l}-0.063 \\
(-1.12)\end{array}$ & $\begin{array}{l}-0.106 \\
(-1.00)\end{array}$ & $\begin{array}{l}-0.005 \\
(-0.57)\end{array}$ \\
\hline Hardware dummy & $\begin{array}{l}-0.127 \\
(-1.51)\end{array}$ & $\begin{array}{c}-0.116^{* *} \\
(-2.59)\end{array}$ & $\begin{array}{l}-0.156 \\
(-1.41)\end{array}$ & $\begin{array}{c}-0.197 * * \\
(-2.03)\end{array}$ \\
\hline Misc. service dummy & $\begin{array}{l}-0.016 \\
(-0.24)\end{array}$ & $\begin{array}{c}-0.0001 \\
(-0.00)\end{array}$ & $\begin{array}{l}0.007 \\
(0.07)\end{array}$ & $\begin{array}{l}-0.005 \\
(-0.05)\end{array}$ \\
\hline The first period dummy & $\begin{array}{l}0.032 \\
(0.96)\end{array}$ & $\begin{array}{l}0.028 \\
(0.85)\end{array}$ & $\begin{array}{c}0.104 * * \\
(1.98)\end{array}$ & $\begin{array}{l}0.044 \\
(0.75)\end{array}$ \\
\hline Intercept & $\begin{array}{l}0.071 \\
(0.82) \\
\end{array}$ & $\begin{array}{l}0.068 \\
(0.88) \\
\end{array}$ & $\begin{array}{l}-0.124 \\
(-0.93) \\
\end{array}$ & $\begin{array}{l}-0.141 \\
(-1.14) \\
\end{array}$ \\
\hline Number of enterprises & 128 & 128 & 207 & 207 \\
\hline$R$-squared & 0.21 & & 0.15 & \\
\hline First-stage $F$ & & $27.56 * * *$ & & $12.95 * * *$ \\
\hline Over-identification test $\chi^{2}$ & & 1.59 & & 0.92 \\
\hline $\begin{array}{l}\text { a. The dependent variable } \\
\text { between the log of the n } \\
\text { number of years betwee } \\
\text { statistics based on the ro } \\
\text { significance at the } 10 \text { perc } \\
\text { b. The lagged employment } \\
\text { and (4). }\end{array}$ & $\begin{array}{l}\text { S the annual } \\
\text { umber of en } \\
n \text { the two o } \\
\text { bust standa1 } \\
\text { cent, } 5 \text { perce } \\
\text { ariable is in }\end{array}$ & $\begin{array}{l}\text { owth rate, a } \\
\text { yees and it } \\
\text { rvations. } \\
\text { rrors. * * } \\
\text { ind } 1 \text { percen } \\
\text { mented in } 2\end{array}$ & $\begin{array}{l}\text { oroximated } \\
\text { lagged valu } \\
\text { Imbers in } \\
\text { and } * * * i \\
\text { levels, respe } \\
\text { S regressic }\end{array}$ & $\begin{array}{l}\text { the difference } \\
\text { ivided by the } \\
\text { theses are } t \text { - } \\
\text { ate statistical } \\
\text { ely. } \\
\text { n columns (2) }\end{array}$ \\
\hline
\end{tabular}


Table 4 Tobit regression estimates of the functions explaining marketing to qualityconscious customers and direct procurement in the sample excluding the leavers, hardware shops, and miscellaneous service providers ${ }^{\mathrm{a}}$

\begin{tabular}{lcccc}
\hline & \multicolumn{2}{c}{ Marketing } & \multicolumn{2}{c}{ Procurement } \\
& $1998 / 2000$ & 2005 & $1998 / 2000$ & 2005 \\
& $(1)$ & $(2)$ & $(3)$ & $(4)$ \\
\hline Years of schooling & $0.041^{*}$ & $0.049^{* *}$ & 0.050 & $0.101^{* *}$ \\
Years of vocational training & $(1.81)$ & $(2.11)$ & $(1.57)$ & $(2.24)$ \\
& $0.081^{* *}$ & 0.038 & 0.058 & 0.107 \\
Years of prior experience & $(2.33)$ & $(0.91)$ & $(1.31)$ & $(1.60)$ \\
Years of management & 0.002 & $-0.025^{*}$ & -0.035 & -0.040 \\
& $(0.10)$ & $(-1.78)$ & $(-1.24)$ & $(-1.19)$ \\
Soap dummy & $-0.029 * * *$ & -0.004 & 0.038 & -0.010 \\
Car repair dummy & $(-2.63)$ & $(-0.36)$ & $(0.26)$ & $(-0.52)$ \\
Parts dummy & $0.721^{* * *}$ & $0.911^{* * *}$ & -0.002 & -0.008 \\
Balance dummy & $(2.79)$ & $(3.17)$ & $(-0.00)$ & $(-0.02)$ \\
& $0.517 * * *$ & $0.462^{* * *}$ & 0.193 & -0.360 \\
Year 2000 dummy & $(3.39)$ & $(2.78)$ & $(0.85)$ & $(-0.92)$ \\
Intercept & -0.060 & -0.091 & -0.067 & -0.297 \\
& $(-0.47)$ & $(-0.71)$ & $(-0.34)$ & $(-1.23)$ \\
\hline Number of enterprises & -0.229 & $-0.386^{*}$ & $0.515 * *$ & 0.205 \\
Number of left-censored & $(-1.16)$ & $(-1.68)$ & $(2.24)$ & $(0.70)$ \\
obs. & 0.116 & & -0.122 & \\
\hline & $(1.12)$ & & $(-0.85)$ & \\
& -0.442 & -0.406 & $-0.962^{* *}$ & $-1.639 * *$ \\
& $(-1.65)$ & $(-1.49)$ & $(-2.31)$ & $(-2.59)$ \\
\hline
\end{tabular}

a. The dependent variable is the fraction of sales revenue from special orders and exports in columns (1) and (2) and the fraction of material cost for procurement from special sources in columns (3) and (4). Numbers in parentheses are $t$-statistics based on the robust standard errors. *, **, and *** indicate the statistical significance at the 10 percent, 5 percent, and 1 percent levels, respectively. 